

\title{
Geochemical Testing and Model Development - Residual Tank Waste Test Plan
}

\author{
K. J. Cantrell, Pacific Northwest National Laboratory \\ M. P. Conrelly, Wastington River Protection Solutions, LLC \\ Richland, WA 99352 \\ U.S. Department of Energy Contract DE-AC27-08RV14800 \\ EOTIECN: DRF UC: \\ Cost Center: $\quad$ Charge Code: \\ B\&R Code: $\quad$ Total Pages: 25
}

Key Words: single shell tanks, residual waste, release rates, performance assessment, energy dispersive spectroscopy, scanning electron microscope, gamma energy analysis, X-ray diffraction, transmission electron microscopy

Abstract: This Test Plan describes the testing and chemical analyses release rate studies on tank residual samples collected following the retrieval of waste from the lank. This work will provide the data required to develop a contaminant reclease model for the tank tesiduals from both sludge and salt cake single-shell tanks. The data are intended for use in the long-tern performance assessment and conceptual model development.

TRAOEMARK DISCLAIMER. Reference herein to any spedilk commercial product, process, or service by trade neme,

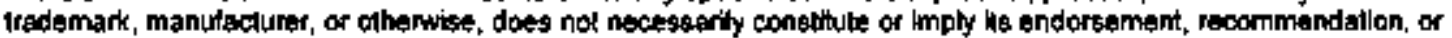
favoring by the United States Govemineml of any agency thereof or its comiractors or subcontractors.

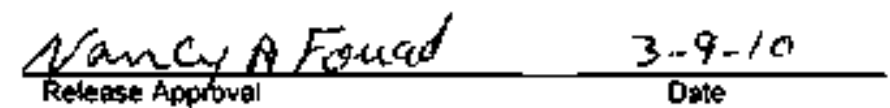

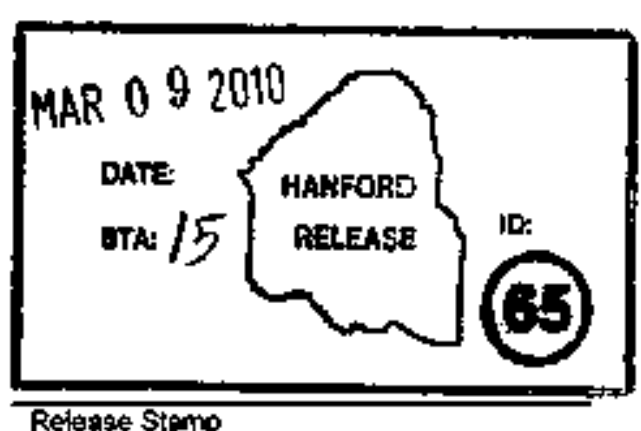

Reieqge Stemp 
RPP-PLAN-43820, Rev. 0

Geochemical Testing and Model Development - Residual Tank Waste

Test Plan

Kirk J. Cantrell

Pacific Northwest National Laboratory

Michael P. Connelly

Washington River Protection Solutions, LLC

Prepared by:

Kirk J, Cantrell

Pacific Northwest Nalional Laboratory

Rishland. Washington

Prepared for:

Washington River Protection Solutions, LLC

Riclland, Waslington

November 9,2010 


\section{TABLE OF CONTENTS}

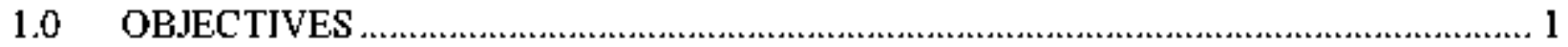

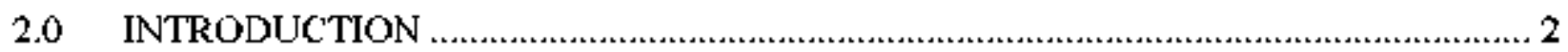

3.0 SCOPE

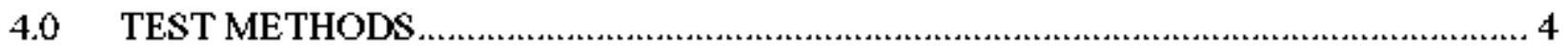

4.1 TIER l - INITIAL CHARACTERIZATION................................................... 5

4.1.1 Gamma Energy Analysis ................................................................... 5

4.1.2 Drainable Liquid ......................................................................... 6

4.1.3 Moisture Content ................................................................................... 6

4.1.4 Carbon Content of Residual Waste..................................................... 6

4.1.5 Microwave Acid Digestion .............................................................. 7

4.1.6 Fusion Elemental Analysis ........................................................ 7

4.1.7 X-ray Diffraction Analysis ............................................................ 8

4.1.8 Short-Term Water Leaching Tests.................................................... 9

4.1.9 Scantuing Electron Microsicopy:Energy Dispersive Spectroscopy........... 11

4.2 TIER 2 - RELEASE MODEL PARAMETER DEVELOPMENT …………........... 11

5.0 QUALITY ASSURANCE/QUALITY CONTROL PROCEDURES …....................... 14

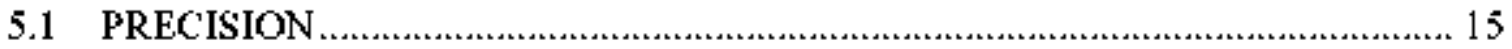

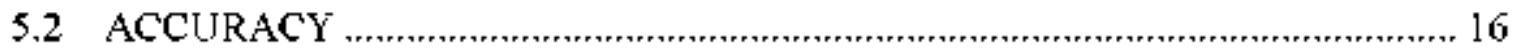

6.0 QUALIFICATIONS:TRAINING...................................................... 17

7.0 REPORTING

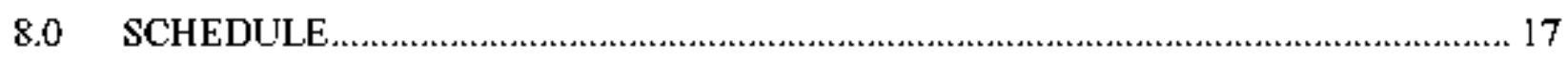

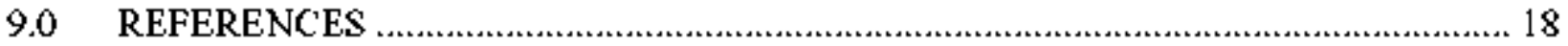

\section{LIST OF FIGURES}

Figure 1. Schenatic of Single Pass Flow-Through Test Apparatus 13 


\section{LIST OF TERMS}

AGG Applied Geology and Geochemistry

APS Advanced Photon Source

ASTM American Society for Testing and Materials

BSE backscattered electron

EDS energy dispersive spectroscopy

EPA U.S. Environmental Protection Agency

HASQARD Hanford Analytical Services Quality Assurance Requirements Document

ICP-AES inductively coupled plasma-atonic emission spectroscopy

ICP-MS inductively coupled plasma-mass spectroscopy/spectrometer/spectrometric

ICP-OES inductively coupled plasma-optical enission spectrometry

LSC liquid scintillation counting

LEPS low energy photon spectrometry

MS matrix spike

MSD matrix spike duplicate

NDIR non-dispersive infra-red

PNNL Pacific Northwest National Laboratory

$\mathrm{QC} \quad$ quality control

RCRA Resource Conservation and Reconery Act of 1976

RPD relative percent difference

SBMS Standards-Based Management System

SEM scanning electron microscopy

SPFT single-pass flow-tlirough

SST single-shell tanks

TEM transmission electron microscopy

WRPS Washington River Protection Solutions, LLC

XAS X-ray absorption

XRD X-ray diffraction 


\subsection{OBJECTIVES}

This Test Plan describes the testing and clemical analyses on waste samples collected firom the Hanford single-shell tanks (SSTs) as part of the closure process. This work will provide the data required to develop a contaminant release model for the tank residuals from both sludge and salt cake SSTs. The data are intended for use in the long-tem performance assessnent and conceptual model development required for closure.

The potential release of contaminants from waste material remaining in the tanks after closure creates a long-term risk to the environment. In order to contidently estimate the release of contamionts from the waste, the following attributes of the contamitants in the residual waste must be characterized.

1. Occurrence - whe1her or not contaminants are present at measurable levels in the was1e.

2. Concentration - mass of the contaminant per mass of solid or liquid waste.

3. Total Amount - concentration of contaminant multiplied times the total uass of the waste. This provides the limiting amount of contaminant available for transport to the environment.

4. Form - phase (solid and/or liquid) containing the contaminant. For contaminants associated witl solids, the type of association is important, including whether it is present as a mineral, component of a mineral, or adsorbed onto the surfaces of the solids.

5. Mobility - ability of the contaminant to transfer into a mobile liquid phase passing through the residual waste. For the residual lank waste, mobility is dependent on the release tate of the contaninant from the source to the solution phase.

The objectives of the testing to be conducted under this plan are to: 1) identify the presence of contaminants in the residual tank waste samples; 2) measure contaminant concentrations; 3) allow for the total contaminant amount to be calculated from the concentration and a separate estinate of the total mass of the waste material; 4) identify the likely form of the contaminant in the waste samples, which will lead to a better understanding of geochemical processes leading to contaminant release to the environiment; and 5) directly measure the mobility of the contamioant by contactiog the waste material with representative leaching solutions. The leaching data will be used to produce source term release models that can be incorporated into the risk assessment calculations. 


\subsection{INTRODUCTION}

This work is being condected for Washington River Protection Solutions, LLC (WRPS) by the Pacific Northwest National Lahoratory (PNNL) as authorized under Contract 100036437 Release 48; WRPS is responsible for estimating long-lerm human health risks from the closed tauks for both the Resource Conservotion and Recovery Act of I976 (RCRA) closure plans and DOE 435.1 performance assessments. Contaminant fate and transport models that describe the nigration of contaninants from the residual tank waste to selected groundwater exposure points are conponents of the risk assessment. Contaminant release models are used as an input to the transport nodels. Because of the lack of specifie information on the occurrenee, concentration. form and mobility of contaminatus in residual waste in the SSTS, considerable uncentainty exists. This leads to the use of conservatism in the choice of conceptual release models, assumed inventories, and long-tem tisk modeling for the residual waste. These laboratory studies are being conducted using actual residual waste samples to characterize the release of contaninants and reduce uncertainty in source-term release modeling.

This Test Flan is a revision of the plan written for work conducted during the previous fiscal years. Tests conducted at PNNL in previous years indicated that most of the laboratory work could be conducted in fumehoods, and would not require the more complicated process of working in a hot cell. In the future, some tank residual waste nay be found to be sufficiently radioactive that hot cells are required for some of the testing, but eurrent evidence suggests that the majority of waste will not exceed Site human health and safety requirements or fumehood dose limits. Also, streamlined technijues were developed along with generally more efficient testing procedures that focus on minimizing sample masses used for testing.

Results of initial testiog of tank wastes by PNNL have shown that contaminatul release for some individual contaminants of concern differs considerably between tanks and certain key contaminants may be less nobile in water than previous conservative estimates predicted. For example, the leachable ${ }^{99} \mathrm{Tc}$ was found to range from 6 to $10 \%$ in the leaching experiments conducted for samples from tanks 241-C-103 (C-103), 24l-C-106 (C-106) and 24l-C-202 (C-202). Past risk assessments for ${ }^{99} \mathrm{~T} c$ release into infiltrating water passing through the tanks have assumed that it was completely water leachable. This has led to the conclusion that ${ }^{99} \mathrm{Tc}$ is the primary risk driver for the groundwater pathway of the long-tern risk assessments performed to date. Recent laboratory results of PNNL studies have shown that ${ }^{9 \%} \mathrm{~T}$ c release from residual waste to groundwater may have been overestimated for some of the tanks. These results also show the need to measure potential release rates of key contaminants of concen (from a longterm risk perspective) from each tank (or tank grouping) because of the variable composition of the different tanks (groups) and the importance of actual release rates to the risk assessment.

Previous results of PNNL studies have also shown that uoderstanding the mechanisms of longterm release of contantinants front some tank wastes might be difficult because of the complex assemblage of solid phases in the tank waste that might impact contaminants release. For example, ${ }^{99} \mathrm{Tc}$ appears to oceur as a trace constituent in Fe oxide and possibly Al oxyhydroxide minerals. Selective extraction tests conducted on C-106 samples indicate that the ${ }^{99} \mathrm{Tc}$ is associated with Fe oxides. The exact form of the ${ }^{99} \mathrm{~T} c$ in the Fe oxides remains to be determined, Further analysis using $\mathrm{X}$-ray absorption (XAS) techniques may be beneficial in this regard. 


\subsection{SCOPE}

At this time, full characterization and release model developnent have been conducted for post retrieval samples from tanks C-106. C-103. C-202. and 241-C-203. A limited characterization and release model development study was also condueted on post retrieval samples collected from tauk 241-C-112 (S-112). For físcal year 2010, full characterization and release model development will be conducted on partial retrieval samples from tank 241-C-108 (C-108) and possibly post retrieval samples from C-108 and/or 241-C-1 10.

The primary contaninants of interest and the focus of the laboratory testing currently are ${ }^{99} \mathrm{Tc}$, ${ }^{129} \mathrm{I}$ and U. These contaninants are of particular interest from the perspective of potential longterm risk, because of their likely presence in the residual tank waste, their relatively high nobility in the environment, and their long half-lives. These three contaninants have been chosen for modeling purposes in the initial assessment of closure for the 241-C Tank Farm (RPP-13310. Modeling Data Package for an Im thal Assessment of Ctostre of the C Tamk Farm). However, the presence and mobility of other contaminants of potential concern will also be evaluated in this study. They include nitrate $\left(\mathrm{NO}_{3}\right)$, nitrite $\left(\mathrm{NO}_{2}{ }^{-}\right), \mathrm{Cr},{ }^{239} \mathrm{Pu},{ }^{241} \mathrm{Am}, \mathrm{As} . \mathrm{Pb}$. ${ }^{60} \mathrm{Co},{ }^{137} \mathrm{Cs}{ }^{90} \mathrm{Sr}$ and ${ }^{63} \mathrm{Ni}$. 


\subsection{TEST METHODS}

Previous work at PNNL has demonstrated that it is possible to do the testing described in this plan in a standard fumehood. It is anticipated that the waste sample radioactivity will be sufficiently low that similar testing of other tank waste samples can be conducted in a standard fumehood approved for radioactive work in the 325 Building. If the radioaclivity of the material is such that laboratory testing must be conducted in a hot cell, then the amount of characterization will be reduced because of logistical (only simple manipulations can be performed inside hol cells using remote robot anus), tine, and budgetary consiraints.

Testing will be conducted using a "tiered" approach similar to the one developed for investigating contaminant fate and transport associated with past SST leaks into the vadose zone sedintents. In this approach, initial screening using relatively simple, inexpensive analytical methods (e.g, batch water leach tests) allow for a general classification of the leachability of the various contaminants from the waste so that less leachable constituents can be identified and targeted for more sophisticated (Tier 2) testing. As discussed in Section 8.0 Schedule, a hold point occurs in the project after the Tier 1 tests have been completed on samples from each SST. The hold point allows for decisions to be nude on the appropriate Tier 2 tests based on the Tier 1 results.

For samples to be studied in fiscal year 2010 , it is anticipated that the following Tier 1 tests will be conducted:

1. Short-temo ( 1 day, 7 day, 30 day) single contact water leaching tests with deionized water and cement pore fluid stinulants

2. Sequential contact waler leaching tests with deionized water and cement pore fluid simulants, five contacts at 7 days for each contact

3. Analysis of extract from microwave acid digestion of as-received waste solid to provide estimates of total leachable constituents

4. Analysis of extract from fussion-acid dissolution of as-received waste solid for total metals and radionuclide analysis

5. Y-ray diffraction (XRD) analysis for identification of erystalline phases (nimerals) present and a general indication of the presence of amosphous material

6. Wet chemical separation of the acid digestions to measure ${ }^{90} \mathrm{~S}$

7. Wet chemical separations of the water and acid extracts to measure ${ }^{129} \mathrm{I}$

8. Total carbon, inorganic carbon, and organic carbon contents of residual sludge and drainable liquor (if available) 
9. Scanning electron microscopy/energy dispersive spectroscopy (SEM/EDS) analysis to locate and determine the composition of zones of high contaminant concentrations, characterize particle morphology and aggregation, and characterize the associations of the different plases present.

Tier 2 and later tests will be conducted when it is nevessary to better understand the release mechanism(s) for a key contaminant that does not conform to simple dissolution/diffusion into the solution phase. The more sophisticated tests that will be considered include:

1. Selective Extraction (Tessier-type) tests to identify solids associated with recalcitrant contamionants

2. Batch oxidation and or reduction experiments to evaluate contaninant release as a result of oxidation or reduction

3. Single-pass flow-through (SPFT) tests to quantify dissoluiion kinetics and contaminant release rates from the solid phases.

4. X-ray absorption spectroscopy to determine oxidation state, speciation, nearest neighbor associations, and chemical bonding information.

5. Transmission electron microscopy (TEM) to assist in phase identification and determine the degree of crystallinity of particles at the submicrometer to nanometer scale.

Details of Tier 1 testing and a general description of Tier 2 tests are provided below.

\subsection{TIER 1 - INITIAL CHARACTERIZATION}

Tier 1 tests will be conducted on up to three C-108 and three 241-C-110 residual waste samples. The Tier l characterization procedures described in this section may be revised during the year as sampling and testing progresses.

\subsubsection{Gamma Energy Allalysis}

Gamma energy analysis will be performed on acid digestion and fusion extract samples for radionuclides such as ${ }^{13 ?} \mathrm{Cs}$. Germanium counters will be efficiency calibrated for distinct geonetries using mixed gamma standards traceable to the Nalional Insitute of Standards and Techuology. Control samples will be nut throughout the analysis to ensure correct operation of the detectors. The controls contain isotopes with photo peaks spanning the full detector tange and will be monitored for peak position, counting rate, and full-width half-maximunt. Details are available in PNNL Technical Procedure AGG-RRL-001. Gamma Energy Analysis Operation and Instrument Verffication tusng the Gene $2000^{\mathrm{TM}}$ Support Sof ware.'

\footnotetext{
' Gen1e 2000 is a regislered trademark of Cajberra Industries, Inc (an AREYA Company), Meriden, Cornecticut
} 


\subsubsection{Drainable Liquid}

The samples of residual tank waste may contain a sufficient quantity of drainable liquid to analyze the composition of this solution. These analyses will be useful because it will represent worst case dissolved concentrations for water that might leak from the tank. In order to measure dissolved concentrations of contaminants and major components in these liquids, as much liquid as possible will be drained from the container holding the waste sample and placed in a separate sample container. Known quantities of deionized water may need to be added to the solution to provide a sufficient quantity for all desired analyses, which will be corrected for dilution when reported. The solution analyses described below for the short-term water leach tests will be performed on the drainable liquid.

\subsubsection{Moisture Content}

The moisture content of the waste material used in testing will be measured in order to calculate dry weight concentrations for constituents in the waste. Dry weight concentrations provide a consistent measurement unit for comparison purposes that eliminates the effect of variable water content on sample concentrations. This measurement will be made on solid samples after the drainable liquid has been separated from the solids. This will need to be taken into consideration when estimating the total residual contaminant source that will reside in the liquid and solid phases.

Gravimetric water contents of the waste samples will be determined using PNNL Technical Procedure AGG-WC-001, Soil Water Content. This procedure is based on the American Society for Testing and Materials (ASTM) procedure ASTM D2216-98, Standard Test Method for Laboratory Determination of Water (Moisture) Content of Soll and Rock by Mass. Two representative sub-samples will be used from each type of waste material provided for testing. If multiple samples of waste material are received and they appear to be uniform in composition and texture, then only one set of two sub-samples will be tested for moisture content. Samples for measurement will be placed in tared containers, weighed, and dried in an oven at $105^{\circ} \mathrm{C}$ until constant weight has been achieved, usually within 24 to 48 hours. The containers will then be removed from the oven, sealed, cooled, and weighed. At least two weighings, after 24-hour heatings, will be performed to ensure that all moisture has been removed. All weighings will be performed using a calibrated balance. The gravimetric water content is computed as the percentage change in soil weight before and after oven drying.

\subsubsection{Carbon Content of Residual Waste}

Carbon in the residual waste may be present as organic carbon and inorganic carbon. It is important to quantify the organic carbon content of the material because it can influence the redox state of the system, provide adsorption sites that retard the movement of contaminants through the material, and if leached from the waste, act as potential complexants for some dissolved metals. Contaminants adsorbed onto solid phase organic matter can also provide a future source of contaminants that can be released to water passing through the residual waste. Solid inorganic carbon is present primarily in carbonate $\left(\mathrm{CO}_{3}{ }^{2}\right)$ minerals. These minerals can neutralize acidic water contacting the waste and provide carbonate species to the solution, which 
may form mobile conplexes with some of the contaminants. For these reasons, the carbon content of the waste will be measured.

The carbon fractions of the residual waste will be determined by measuring the total carbon content of the material and then measuring the inorganis fraction on a duplicate sample. The organic carbon fraction is calculated by subtracting the inorgatic fraction concentration from the concentration of total carton. The PNNL procedure AGG-TOC-001, Operation of Carbon Analy=er (TOV-V + SSH-5000A + ASI-V (Shmadzw) is similar to ASTM E1915-07, Stondord Test Methods for Analysis of Metal Bearing Ores and Related Materats by Combustion Infrated-Absorpiton Spectrometry: Total carbon will be measured using a Shinadzu SSM5000A Carbon Analyzer' with combustion at approximately $980^{\circ} \mathrm{C}$. Inorganic carbon content will also be determined using a Shinadzn SSM5000A Carbon Analyzer. For this analysis, the carbon in the sample is bumed in a combustion tube to form carbon dioxide $\left(\mathrm{CO}_{2}\right)$. A carrier gas containing the carbon dioxide flows fron the combustion tube to a non-dispersive infra-red (NDIR) gas analyzer. The signal from the NDIR gas analyzer forms a peak whose area is proportional to the carbon concentration of the sample.

\subsubsection{Microwave Acid Digestion}

The bulk compositions of the sludge solids will be detenmined using PNNL Tecluical Procedure AGG-MARS-001, Operation of the MARS 5 Microwave Accelerated Reaction System, a modified version of U.S. Environmental Protection Agency (EPA) SW-846 Method 3052 (EPA 1996). The modifications to Method 3052 consist of 1 ) decreasing the concentrated nitric acid ( $\mathrm{HNO}_{3}$ ) volume from $9 \mathrm{~mL}$ to $5 \mathrm{~mL}$ and 2) increasing the deionized water volume from the recommended volume of 0 to $5 \mathrm{~mL}$ up to $10 \mathrm{~mL}$. This method is used to measure the elemental composition of the sludge, but is not appropriate for the anion concentrations due to the addition of acids used in the analyses. The anion compositions were measured separately in solutions obtained by water leaching of the solids.

In the procedure, $300 \mathrm{mg}$ of the sample is placed in a Teflon ${ }^{5 / 2}$ microwave digestion vessel and $10 \mathrm{~mL}$ water, $5 \mathrm{~mL} 16 \mathrm{M} \mathrm{HNO}_{3} 2 \mathrm{~mL} 12 \mathrm{M} \mathrm{HCl}$ and $1 \mathrm{~mL} 29 \mathrm{M} \mathrm{HF}$ are added to the sample: the vessel is then sealed and placed in a microwave-assisted digestion system. The samples are treated at the EPA recommended temperatures and times. The sample is then allowed to cool and 0.45 grans of $\mathrm{H}_{3} \mathrm{BO}_{3}$ is added to the digestate and shaken by hand. Samples are filtered

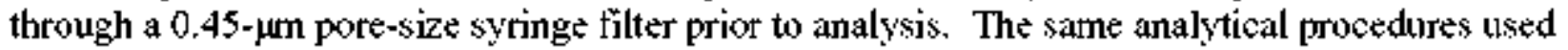
to analyze the extracts will also be used to measure $\mathrm{pH}$, conductivity, cations, carbon, and gross alpha/beta radjoactivity in the supernatants from the leaching tests (see Section 4.1.8 below).

\subsubsection{Fusion Elemental Analysis}

For some samples with very high Al content (such as S-1 12), it was delemined that the microwave digestion technique nay not completely solubilize the entire sample. As a result fusion analysis will also be used for delermitting bulk compositions of the sludge solids. The

\footnotetext{
' The Shimadzu SSM5000A Carbon Analyzer is a product of Shimadzu Scientific Instruments. Columbia, Maryland. a subswilary of \$umadzu Corporation, Kyot, Japan

${ }^{2}$ Teflonie is a registered tratemark of I E du Pont de Nemours and Company, Wilmongton, Delaugate
} 
PNNL Technical Procedure, AGG-ESL-001, Solubrluzatron of Metals from Solds Using a $K O H \cdot \mathrm{NO}_{3}$ Fusion, will be used. This method is used to measure the elemental composition of the sludge, but is not appropriate for the anion concentrations dne to the addition of acids used in the analyses. The anion compositions were measured separately in solutions obtained by water leaching of the solids (see Section 4, 1,8 below).

The potassium hydroxide $(\mathrm{KOH})$-potassium nitrate $\left(\mathrm{KNO}_{3}\right)$ fusion-dissolution procednre is the nost commonly used method for solubilization of Hanford tank sludge samples for clemical analysis by inductively coupled plasnu-mass spectroscopy (ICP-MS) and other methods (WHC-SD-WM-TI-648, Tank Charactertatton Reference Gtide, WHC-EP-0806. Tank 241-T-1/ Charactertation Report. PNNL-13364. Inorgant and Radrochemeal Analysis of 241-C. 104 Tank Waste; PNNL-13452, Yitrification and Product Tesing of C. 104 and AZ-102 Pretreated Situge Mixed with Flow'sheet Ouantmes of Secondary Wastes). Benefits of this procedure include more effective metathesizing of insoluble salts into acid soluble hydroxides; completed fusion at relatively low temperature $\left(550^{\circ} \mathrm{C}\right)$ compared to other fluxing agents, such as $1100^{\circ} \mathrm{C}$ for the lithium metaborate $\left(\mathrm{LiBO}_{2}\right)$ fluxing agent: and use of $\mathrm{Ni}$ or $\mathrm{Zr}$ crucibles, as opposed to the more costly Pt crucibles.

\subsubsection{X-ray Diffraction Analysis}

Y-ray diffraction allows for the identification of crystallioe solids (minerals) in the tank waste material. The identification of these minerals is important because their solubility in water will provide an upper limit on potential dissolved concentrations of the components of the minerals. The release of contaminant trace constituents in the minerals may also be linited by nineral solubility. For some samples, the XRD patterns nay also provide qualitative infomation about amorphous solid that may exist io a waste sample and may watrant study by Tier 2 techniques.

Y-ray diffraction sample preparation will be perforned using PNNL Operating Procedure RPL-PIP-4, Prepoming Sealed Rodhouctive Samples for XPD and Other Purposes. In this procedure, a slumsy of approxinately $10 \mathrm{mg}$ of the tank waste material and $0.3 \mathrm{~mL}$ of collodian is made to minimize air dispersion of the fine-grained solid. A small quantity of the slurry (containing about 1 to $2 \mathrm{mg}$ of solid) is then placed on the XRD sample holder by dropper. The holder and sample are enclosed in a plastic casing to eliminate sample loss during transit and analysis. Samples are analyzed on a Scintag XRD unit equipped with a Pelter thermoelectrically cooled detector and a Cu x-ray ube. ${ }^{1}$ Randonly oriented whole waste samples will be scanned from 2 to $65^{\circ} 2 \theta$ with a dwell time of 14 seconds. A trace quantity of high purity quartz ( $\mathrm{SiO}_{2}$ ) powder or reference-naterial corundum powder ( $\alpha-\mathrm{Al}_{2} \mathrm{O}_{3}$, alunina) (National Institute of Standards and Techuology Standard Reference Matertal 676. Alamna Internal Standard for Quantiative Analysis by $Y$-ray Powder Diffraction [NIST SRM 676A]) will be added to each sample slurry as intemal $2 \theta$ standard to correct for any observed peak shifts caused by slight nisalignments of the mounted samples. Scans will be collected electronically and processed

\footnotetext{
'Instruments 1dentified in this Test Plan by specific manufacturer's name may change depending on their avallability For example durusg 201\%, the Scintag XRD unit is expected to the replaced by a new. state-rif-the-art XRD whit purchased with FNNL funding
} 
using the JADE ${ }^{\text {W }}$ XRD pattern processing software'. Identification of the mineral phases will be based on mineral powder diffraction files published by the Joint Committee on Powder Diffraction Standards International Center for Diffraction Data.

\subsubsection{Short-Term Water Leaching Tests}

The water-soluble constituents of the residual waste will be measured using short-term (from 16 hours to as long as 1 month) leaching tests. These tests will provide an initial indication of the mobile constituents of the waste that would dissolve into water contacting the material in the future. The concentrations of contaminants in leachates from these short-term tests will be indicative of early, future releases from the tanks when readily-soluble solids are still present. These concentrations may not be representative of the long-term concentrations after the soluble solids have been dissolved and removed from the source waste material, and the remaining tank waste is less soluble. The release of contaminants from less soluble solids may be kinetically controlled, and could be measured by techniques considered for Tier 2 testing.

The Tier 1 water leach tests will be conducted using $-0.3 \mathrm{~g}$ (wet weight) of waste and $30 \mathrm{~mL}$ of deionized water for each test. This amount of water is needed to conduct the solution analyses described below. The deionized water will be added to screw cap jars containing the waste sample. The jars will be sealed and briefly shaken by hand, then placed on a mechanical orbital or linear shaker. Two identical jars will be prepared for each distinctive type of waste material. The jars will be sacrificed for analysis after contact periods of one day and four weeks. Solution composition measurements over this time frame will provide information on the short-term variability of contaminant release. At each sampling interval, the solids will be allowed to settle in the jar until the supernatant liquid is fairly clear. The supernatant will be carefully decanted and separated into unfiltered aliquots for conductivity and $\mathrm{pH}$ determinations, and filtered aliquots (passed through 0.45 - $\mu \mathrm{m}$ pore-size membranes) for anion, cation, carbon, and radionuclide analyses (described below). This water leach test follows the general guidelines of ASTM D3987-85(2004), Standard Test Method for Shake Extraction of Solid Waste with Water with changes made to accommodate the small mass of material available for testing and longer test duration. Duplicate testing will be conducted for each time period.

Similar leaching tests will be eonducted to simulate leaching with pore waters derived from fresh and aged cements. These tests will use solutions that are near saturation with respect to portlandite $\left[\mathrm{Ca}(\mathrm{OH})_{2}\right]$ or calcite $\left(\mathrm{CaCO}_{3}\right)$ to simulate the compositions of fresh and aged cement pore waters, respectively.

4.1.8.1 pH and Conductivity. Two, approximately $3-\mathrm{mL}$ aliquots of the unfiltered supernatant will be used for $\mathrm{pH}$ and conductivity measurements. Solution $\mathrm{pHs}$ will be measured with a solid-state $\mathrm{pH}$ electrode and a $\mathrm{pH}$ meter calibrated with appropriate buffers at $4,7,10$, and 12. Conductivity will be measured and compared to $\mathrm{KCl}$ standards with a range of $0.001 \mathrm{M}$ to $5.0 \mathrm{M}$. The measurement of $\mathrm{pH}$ and conductivity are covered in procedures AGG-pH-001, $\mathrm{pH}$ Measurement and AGG-EC-001, Electrical Conductivity Measturements, respectively.

\footnotetext{
${ }^{1}$ JADE@ is a registered trademark of Materials Data, Inc, Livermore, California.
} 
4.1.8.2 Anions. The supernatant will be analyzed for anions using an ion chromatograph. Fluoride $\left(\mathrm{F}^{-}\right)$, acetate $\left(\left[\mathrm{CH}_{3} \mathrm{COO}\right]\right)$, fomate $\left(\mathrm{CHOO}^{-}\right)$, chloride $\left(\mathrm{Cl}^{-}\right)$, bromide $\left(\mathrm{B}^{-}\right)$, nitrate $\left(\mathrm{NO}_{3}{ }^{\prime}\right)$, witrite $\left(\mathrm{NO}_{2}{ }^{\circ}\right)$, carbonate $\left(\mathrm{CO}_{3}{ }^{2}\right)$, phosphate $\left(\mathrm{PO}_{4}{ }^{3 \cdot}\right)$, sulfate $\left(\mathrm{SO}_{4}{ }^{2}\right)$, and oxalate $\left(\mathrm{C}_{2} \mathrm{O}_{4}{ }^{2}\right)$ will be separated on a Dionex AS17 colunun with a gradient elution of $1 \mathrm{mM}$ to $35 \mathrm{mM} \mathrm{NaOH}$ and measured using a conductivity detestor. Anion analysis is determined by PNNL Technica] Procedure AGG-IC-001, Determmations by Ion Chromatography; (IC). The procedures methodology is based on EPA Method 9056A (EPA 2007b) with the exception of using the gradient elution of $\mathrm{NaOH}$.

4.1.8.3 Cations and Trace Metals. Analysis of the major cations (including $\mathrm{Al}, \mathrm{Si}, \mathrm{Ca}, \mathrm{Mg}$, $\mathrm{Na}, \mathrm{K}, \mathrm{Fe}, \mathrm{Ni}, \mathrm{Sr}, \mathrm{Zr}$ and $\mathrm{Mn}$ ) in the supernatant will be performed by indictively coupled plasma-atomic emission spectroscopy (ICP-AES) using procedure PNNL-AGG-ICP-AES. Indtactwely: Conpled Plasma - Optical Emsston Spectrometry (ICP-OES) Analysus. Higli-purity calibration standards will be used to generate calibration curves and verify continuing calibration during the analysis run. Dilutions of $100 \mathrm{x}, 50 \mathrm{x}, 10 \mathrm{x}$, and $5 \mathrm{x}$ will be made of each sample for analysis to investigate and correc for matrix interferences. The second instrument, used to analyze trace metals including $\mathrm{Cr}, \mathrm{As}, \mathrm{Se}, \mathrm{Ag} . \mathrm{Cd}, \mathrm{Pb},{ }^{99} \mathrm{Tc}$, and $\mathrm{U}$, will be an inductively coupled plasma-nass spectrometer (ICP-MS) using the PNNL-AGG-415. Indtctively Coupled Plasma Mass Spectrometric (ICP.MS) Analysis, Rev. 2 method. This method is similar to EPA Method 6020A (EPA 2007a). Typical instrument detection linits for the ICP-AES and ICP-MS iostruments are at the ppb level.

4.1.8.4 Radionuclides. In addition to the radionuclides listed above that will be analyzed in solution by ICP-MS, shor-lived radionuclides, such as ${ }^{90} \mathrm{Sr},{ }^{137} \mathrm{Cs}$. Eu isotopes. ${ }^{60} \mathrm{Co}$, and sone of the actinides, will be analyzed by conventional counting methods. ${ }^{137} \mathrm{Cs},{ }^{60} \mathrm{Co}$ and the Eu isotopes will be measured by ganima energy analysis (using methods discussed above under 4.1.1 Ganuna Energy Analysis). ${ }^{90} \mathrm{Sr}$ will be analyzed by wet chemical separation and liquid scintillation counting. while the actinides will be done by wet chenical separation and alpha spectroscopy (AGG-RRL-005, Counting Procedure for Alpha Spectrometry).

Gross alpha and beta measurement will be made on the supernatants. For each sample, a $\sim 1-\mathrm{mL}$ sample volume will be placed in a $20-\mathrm{mL}$ tared liquid scintillation vial and weighed. A 15-nL seintillation cocktail will then be added and the samples mixed and counted on a Wallace model 1415 liquid scintillation counter as prescribed in procedure AGG-RRL-002, Liqua Somtilation Cotming and Instrument Verification ustng the 1400 DSA Stppont Sof ware.

As described above in Sections 4.1.6 and 4.1.7, radionuclides in the tank waste solids will be measured by a number of methods that include $\mathrm{HNO}_{3}$ digestion ICP-MS (majority of isotopes) and water $/ \mathrm{NaOH}$ digestion/liquid sciutillation counting (LSC) or low energy photon spectrometry (LEPS) $\left.{ }^{129} \mathrm{I}\right)$.

4.1.8.5 Alkalinity and Carbon. The alkalinity and inorganic/organic carbon content of the supernatants will be measured using standard titration with acid and a carbon analyzer. respectively. The alkalinity procedure is equivalent to the U.S. Geological Survey National Field Manual for the Collection of Water-Quality Data Section $6.6, "$ Alkalinity and Acid Neutralizing 
Capacity, Version 3.0" (Rounds 2006). Inorganic and organic carbon on the supernatants will be determined using a carbon analyzer and PNNL Technical Procedure AGG-TOC-001.

\subsubsection{Scanning Electron Microscopy/Energy Dispersive Spectroscopy}

Scanning electron microscopy and EDS analysis of the uoleached and leached tank wasle solids will allow us to characterize the type, distribution, and morphology of solid phases present in the tatuk wasle. Energy dispersive spectroscopy will provide the capability to measure the composition of individual mimerals and amorphous solids observed in the SEM electron micrographs. The mounts used for SEM!EDS will typically consist of double-sided carbon tape attached to standard Al mounting subs. For each mount, a small alicuot of solid waste sample will be placed on the exposed upper surface of the $C$ tape, and the mount then coated with $C$ using a vacuum sputter-coater to improve the conductivity of the samples. A JEOL JSM 840 SEM' will be used for high-resolution imaging of micrometerisubmicrometer-sized particles from the waste samples. The SEM system is equipped with an Oxford Links ISIS $300 \mathrm{EDS}^{2}$ that will be used for qualitative elemental analysis. Operating conditions will typically consist of 10 to $20 \mathrm{keV}$ for $\mathrm{SEM}$ imaging and $20 \mathrm{keV}, 100$ live seconds for the EDS analyses. High-resolution electron micrographs will generally be obtained in backseattered electron (BSE) enission to help identify particles that contain elements with large atomic number such as $U$.

\subsection{TIER 2 - RELEASE MODEL PARAMETER DEVELOPMENT}

After the general characteristics of the tank waste material have been detennined by the Tier 1 tests, the details of subsequent tests will be decided during diseussions with WRPS. These tests may include one or more of the following:

1. Selective extraction (Tessier-type) tests to identify solids associated with recalcitrant contaminants.

2. X-ray absorption spectroscopy to determine oxidation state, speciation, neares1 neighbor associations, and chemical bonding information.

3. Single-pass flow-tlurough tests to quantify dissolution kunetics and contamunant release rates from the solid phases.

4. Batch oxidation or redection experiments to evaluate contaminant release as a result of oxidation or reduction

5. Transmission electron nucroscopy.

Brief descriptions of these tests are provided in this section.

\footnotetext{
' The JEOL JSM-840 scanning electron microscope is a product of JEOL-USA, Inc, Peabody, Massachusetts

${ }^{2}$ The Oxford Litlis ISIS 300 EDS is a protuct of Oxford lnstruments America Inc, Concorth, Massachusetts
} 
Selective extraction tests may be used to aid in the identification of phases controlling the release of contaminants to water. In selective extractions, the solid phase is contacted with a solution that is designed to dissolve only one type of mineral that might contain the contamituant. For example, the following solutions may be used to extract certain minerals:

1. $0.1 \mathrm{M}$ acet ic acid acetate buffer $(\mathrm{pH} 4.65)$

2. $0.1 \mathrm{M}$ formic acid/formate buffer $(\mathrm{pH} \mathrm{3.5)}$

3. $\mathrm{HCl}(0.25 \mathrm{M})$.

The acetic acid solution will dissolve carbouate ninerals, but oot Fe or Al oxyhydroxide solids. The formic acid solution will tenove the carbonates and the Al oxylhydroxides, but not the $\mathrm{Fe}$ oxides. Finally, the HCl solution will dissolve all the above phases. This procedure will be used for selected ligh-interest contaminants (like ${ }^{99} \mathrm{Tc}$ ) when Tier 1 tests slow that it is not fully released during the water leach tests.

X-ray absorption spectroscopy may be conducted on a limited number of solution and solid samples when it is necessary to identify the valence state and/or nearest neighbor of a contaminant in a solid or solution complex. These analyses cau be done at DOE multi-user facilities such as the Advanced Photon Source (APS) at Argonne National Laboratory. Access to instrument time at such facilitice requires sufficient lead time to prepare and subnit a user proposal and to receive a priority rating and approval of that proposal describing the studies and estimate of required instrument time.

The selective extraction tests may be conducted using the SPFT method. This procedure is deseribed in AGG-SPFT-001, Single Pass Flow-Through Text hethod and shown in Figure 1. In addition 10 its use for the selective extraction tests, the SPFT may also be used to quantify the release of contaminants from the tank waste after the more soluble salts and faster equilibrating minerals have been leached from the waste material. MeGrail et al. (2001) proposed the use of a kinetic rate equation to model the long-term performance and contaninant release from lowactivity waste glass to be disposed of at Hanford. This model may be appropriate for the later phases of contaminant release from the tanks. The SPFT can be used to measure the kinetic rate law parameters $\left(k, E_{a}\right.$ and $\eta$ ) necessary for the release rate equation. A stale-of-the-art SPFT apparatus for conducting tests of reaction kinetics is available at PNNL.

Because of the known presenes of organic compounds and other teducing species (such as nitrite) in tank sludge and the possibility that reducing conditions can affect contaminant mobility (especially for ${ }^{99} \mathrm{Tc}, \mathrm{U}$, and $\mathrm{Cr}$ ), oxidation experiments and measurements of sludge reduction capacity niay be conducted. The release of contaminant into solution will be measured during the oxidation experiments and the total concentration of reactive reductants will be estimated by the capacity measurements. The batch oxidation experiments will be earried out by contacting $\sim 0.3 \mathrm{~g}$ of the tank wasle with $40 \mathrm{~mL}$ of $3 \%$ and $30 \% \mathrm{H}_{2} \mathrm{O}_{2}$. After the reactions have ceased, the supematant will be analyzed to see if the contaninants of interest have been reased. The organic $\mathrm{C}$ content of the sludge will be measured before and after $\mathrm{H}_{2} \mathrm{O}_{2}$ addition to measure the amount oxidized. 
Figure 1. Schenatic of Single Pass Flow-Through Test A pparatus

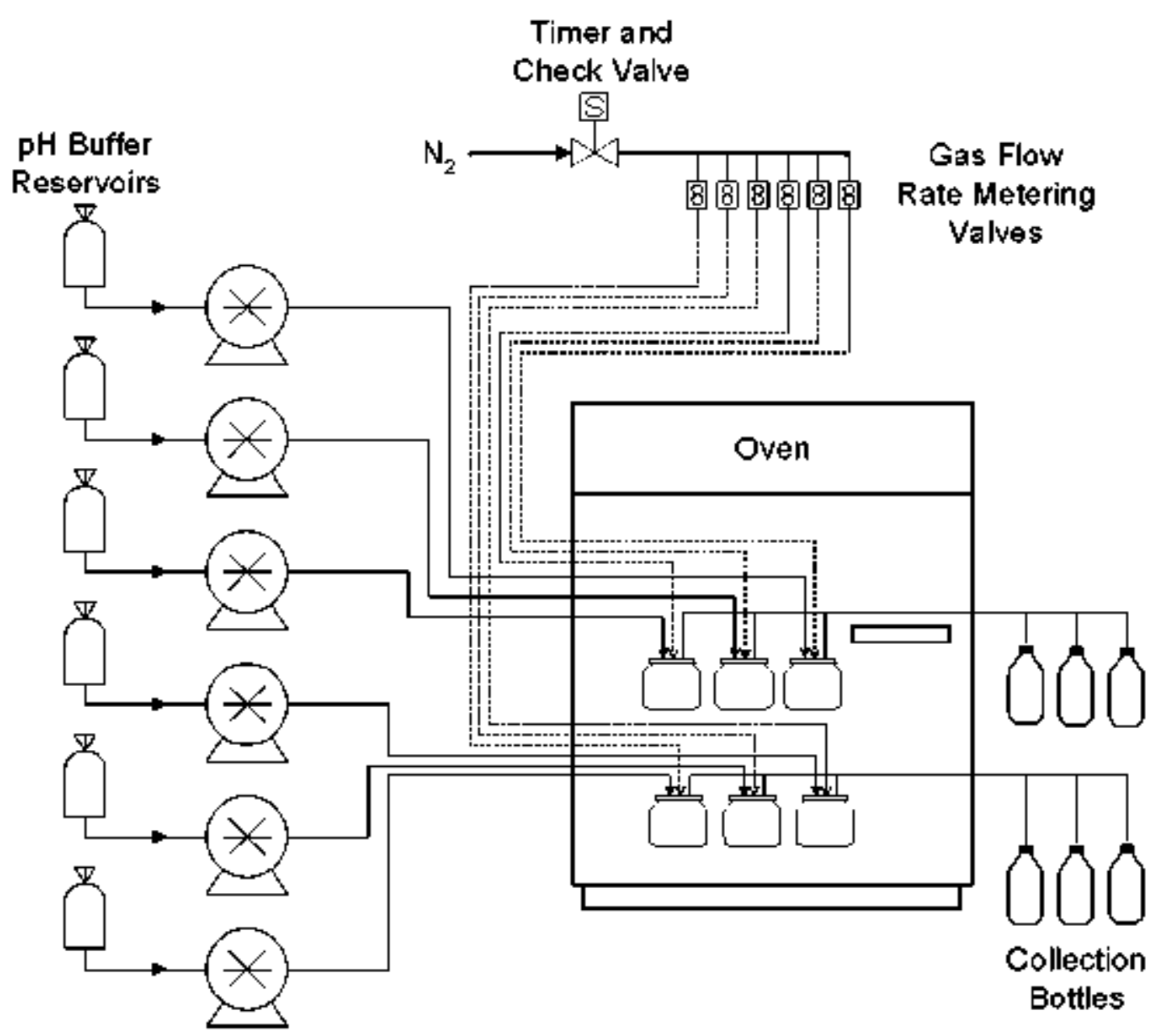

Pumps

The reduction capacity will be measured by contacting $\sim 0.3 \mathrm{~g}$ of the waste with $3 \mathrm{~mL}$ of a chromate $\left(\mathrm{CrO}_{2}{ }^{4}\right)$ solution that should be sufficient to oxidize all the organic and inorganic reductants in the solid phase and porewater (Lee and Batchelor 2003). The reducing capacity will be calculated from the amount of chromate reduosd to $\mathrm{Cr}$ (III).

Transmission electron microscopy for analysis of solid particulates has the advantage over XRD and SEM/EDS analyses it that TEM can more effectively isolale a particular phase such that compositional and structural information specific to the phase can be betler resolved.

Transmission alectron microscopy allows inspection of objects in an ultra thin specimen in areas of a few nanometers in diameter. Infomation that can be provided by TEM analysis can include size, shape and arrangement of the particles which make up the specinen; arrangement of atons in the specinien and their degree of srystallinity; detection of atomis-seale defects: and if so equipped, elements and compounds in the specimen.

Following the Tier 1 and Tier 2 testing, PNNL will provide a recommendation on the appropriate source term model to use in the risk/performance assessment. 


\subsection{QUALITY ASSURANCE/QUALITY CONTROL PROCEDURES}

All quantitative chemical analyses will be conducted in accordance with the requirements of Title 10 of the Code of Federal Regulations, Part 830.120 "Quality Assurance" and the Hanford Analytical Services Quality Assurance Requirements Document (HASQARD). These requirements will be implemented using PNNL's on-line QA Plan, PNNL-SA-63118, Conducting Analytical Work in Support of Regulatory Programs. PNNL-SA-63118 is based on the requirements of U.S. DOE Order 414.1C, Quality Assurance as described in PNNL's Standards-Based Management System (SBMS), the HASQARD, relevant elements of ASME NQA-1-2004, Quality Assurance Requirements for Nuclear Facility Applications (QA), as well as recognized industry standards (e.g., EPA, ASTM, American National Standards Institute). Note that some qualitative analyses, such as those obtained by EDS, are not conducted according to these standards due to the nature of their measurement and sample geometry and the lack of qualitative internal standards.

The quality of the data produced during this laboratory testing program will be assured through the use of an approved Test Plan, implementation by experienced laboratory personnel (described in the following section) and the use of laboratory quality control (QC) samples to evaluate experimental and analytical results. In addition, most of the experiments (short and long-term leaching tests, SPFT) will be run in duplicate for at least one of the runs so that comparability can be determined. The remainder of this section describes the laboratory QC samples.

Quality control samples are samples introduced into the analysis stream, whose results are used to review data quality and to calculate the accuracy and precision of the chemical analysis program. The purpose of each type of QC sample, collection and analysis frequency, and evaluation criteria are described in this section. Collection and analysis minimum frequencies for QC samples are summarized in the following table.

\begin{tabular}{|l|c|}
\hline \multicolumn{1}{|c|}{ SAMPLE TYPE } & FREQUENCY \\
\hline Experiment Blanks & $10 \%$ \\
\hline Experiment Duplicates & $10 \%$ \\
\hline Matrix Spike & $5 \%$ \\
\hline Matrix Spike Duplicates & $5 \%$ \\
\hline
\end{tabular}

Experiment blanks will be used to determine if contamination is introduced into samples by general laboratory testing procedures. Experiment blanks will consist of analyte-free, deionized water transferred directly into sample containers in the laboratory area where the experiments are being conducted. These blanks will be submitted blind to the analytical laboratory with sample numbers that are indistinguishable from primary samples. Blank samples will be analyzed for the same parameters as associated experimental samples.

Experiment duplicate samples will be used to check for sampling and analysis reproducibility. These duplicates will be submitted to the analytical laboratory at a frequency of $10 \%$ of the 
experimental samples for all liquid phase analytical methods. Control limits for duplicate precision are $30 \%$ relative percent difference (RPD) for aqueous samples and $50 \%$ for solid samples.

Matrix spikes and matrix spike duplicates (MSs/MSDs) are used to assess sample matrix interferences and analytical errors, as well as to measure the accuracy and precision of the analysis. The MSs:MSDs will be collected and analyzed at a rate of $5 \%$ of the experimental samples for each matrix and analytical method or at least one for each analytical batch, whichever frequency is greater. Known concentrations of analytes are added to environontal samples; the MS or MSD is then processed through the entire analytical procedure and the recovery of the analytes calculated. Results are expressed as percent recovery of the known spiked amount (and RPD for MSMSD pairs).

Because MS/MSD samples measure the matrix interference of a specific matrix, only MS/MSD samples from this investigation will be analyzed, and not samples from other projects. The MS MSD samples will be analyzed for the same parameters as the associated experimental samples in the same QC analytical batch.

In addition to the results of the analysis of blank samples, the primary data quality indicators that will be eraluated ate precisjon and aceuracy (bias). They are discussed below.

\subsection{PRECISION}

Precision is defined as the degree of agreement between or among independent. sinilar, or repeated measures. Precision is expressed in terns of analytical variability. For this project. analytical variability will be measured as the RPD or coefficient of variation between analytical laboratory replicates and between the MS and MSD analyses. Monitoring variability will be measured by analysis of blind field replicate samples.

Precision will be calculated as the RPD as follows:

$$
\% R P D_{r}=\frac{\left.2 O_{r}-D_{r}\right)}{\left(O_{1}+D_{r}\right)} \times 100 \%
$$

where:

$$
\begin{aligned}
& \% \mathrm{RPD}_{\mathrm{r}}=\text { Relotwe percent dfference for compotind } 3 \\
& O, \quad=\text { Value of compound in ongmal sumple } \\
& \text { D. = latie of compotind in diplacate sample }
\end{aligned}
$$

The resultant RPD will be compared to aceptance criteria and deviations front specified limits reported. If the aceeptance criteria are not net a justification will be provided of why the acceptability limits were exceeded and appropriate corrective actions will be implemented, if necessary. The RPD will be reviewed during data guality review, and deviations from the 
specified limits will be noted and the effect on reported data commented upon by the data reviewer.

\section{$5.2 \quad$ ACCURACY}

Accuraty is the amount of agreement between a measured value and the true value. It will be measured as the percent recovery of MSs/MSDs. Additional potential bias will be cuantitated by the analysis of blank samples.

Accuracy will be calculated as percent recovery of analytes as follows:

$$
\% R_{1}=\left(Y_{i}+X_{1}\right) \times 100 \%
$$

where:

$$
\begin{aligned}
\% R_{1}= & \text { percent recovery for compond } \\
Y_{1}= & \text { meastired analyte concentration in sample } \\
& \text { (measured mins orgthat sample concentration) } \\
X_{i}= & \text { known andyte concentration in sample }
\end{aligned}
$$

The resultant percent recoveries will be compared to acceptance criteria and deviations from specified limits will be reported. If the objective criteria are not met, a justification of why the acceptability limits were exceeded will be provided and appropriate corrective actions will be implemented, if necessary. Percent recoveries will be reviewed during data quality review, and deviations from the specified limits will be noted and the effect on reported data commented upon by the data reviewer. 


\subsection{QUALIFICATIONS/TRAINING}

The Applied Geology and Geochemistry (AGG) Group of the Pacific Northwest National Laboratory has a long history of supplying geochemical data for near-field projects (especially for the Hanford Site and other radionuclide contaminated areas). The Group has been the niajor supplier of geochenical data for many Hanford perfomance assessments.

The PNNL manager for this project is Kirk $J$. Cantrell, who has a Ph.D. degree in Geochenistry with a minor in groundwater lydrology. He has 20 years of experience designing and conducting laboratory and field studies of contamiuated soils, including radionuclide contamionated materials. Supporting the project manager are well qualified. experienced staff ín the AGG Group that have been involved with previous laboratory studies of the Hanford tank wastes and associated contaninated soils. Resumes for all staff are available upon request.

\subsection{REPORTING}

Monthly progress reports that include both technical and financial information will be subnitted by the $15^{\text {th }}$ of the following month. Additional project reports will be prepared and delivered according to the following schedule. These reports shall be issued following PNNL procednres. They will be delivered in hard copy and Hanford site standard software.

\begin{tabular}{|c|c|c|}
\hline Task & Delivernble & Due Date \\
\hline 1 & $\begin{array}{l}\text { Draft update of Geochem ical Testinis and Mixdel Development - } \\
\text { Resıdual Tank Hiaste Test Plan }\end{array}$ & $1102 / 2009$ \\
\hline 2 & Recerve comments and finalize Test Plan & 11 ingisong \\
\hline 3 & Draft $6-108$ Release Rate Study Report & $06,08 / 2010^{9}$ \\
\hline 4 & $\begin{array}{l}\text { Final PNNL Report describung the release model for single-shell } \\
\text { tank C-108 residual waste }\end{array}$ & $07 / 482019$ \\
\hline 5 & Retum Samples to 222-S Laboratory & $0810 / 2010$ \\
\hline 6 & $\begin{array}{l}\text { Prov ide Bi-W Wekly Status Reports of the Geochemical Testung andl } \\
\text { copies of applicable laboratory notebook }\end{array}$ & $\begin{array}{l}\text { B--Weekly commencing at } \\
\text { slart of testing }\end{array}$ \\
\hline 7 & General Support & As-Requested \\
\hline
\end{tabular}

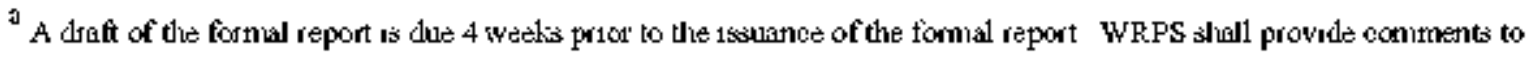
PNWL wothen 2 wezks of receivng traft report WRPS comments shall be incorporated un the final report

PNNL = Pacific Northwest National Laboratory

WRPS = Washungten RuYer Procetion Solunons, LLC.

\subsection{SCHEDULE}

The schedule of activities for this project is shown in the table above. Due dates for the Waste Constituent Study reports cannot be estimated because they are based on tank retricual and sampling dates that are constantly clianging. 
RPP-PLAN-43820, Rev. 0

\subsection{REFERENCES}

AGG-EC-001, 2009, Electncal Conductmity Measurements, Pacific Northwest National Laboratory, Richland, Washington.

AGG-ESL-001, 2006, Solubtuzation of hetals frow Soluds Using aKOH-KNO $F_{3}$ tston, Rev. 1, Pacific Northwest National Laboratory, Richland. Washington.

AGG-IC-00 1, 2004, Detemmations by Ion Chromatography (IC). Pacific Northwest National Laboratory, Richland, Washington.

AGG-MARS-001. 2004, Operation of the MARS 5 Mrcrowave Accelerated Reaction System. Pacific Northwest National Laboratory, Richland, Waslington.

AGG-pH-001, 2005, pH Meashrement, Pacific Northwest National Laboratory, Richland, Washington.

AGG-RRL-001, 2004, Gamma Energy Analysts Operation and Instrument Ierification tising the Gene $2000^{N}$ Support Software, Pacific Northwest National Laboratory, Richland, Washinglon.

AGG-RRL-002, 2006, Lighd Scmtilation Countmg and Instrument Verfication wsing the 1400 DS.A Support Sofiware, Pacific Northwest National Laboratory, Richland. Washington.

AGG-RRL-005, 2004, Comtmg Frocedure for Alpha Spectrometry, Pacific Northwest National Laboratory, Richland, Washington.

AGG-SPFT-001, 2003, Single Pass Flow-Throngh Test Method. Rev. 0. Pacific Northwest National Laboralory, Richland, Washinglon.

AGG-TOC-001, 2004, Operatron of Carbon Analy-er (TOV-V + SSM-5000A + ASI-Y (Shmodich), Pacific Northwest National Laboratory, Richland, Washington.

AGG-WC-001, 2005, Son Water Content, Pacific Northwest National Laboratory, Richland, Washington.

ASTM D2216-98, 1998, Standard Test Method for Laboratory Determ nation of Water (Monture) Content of Son and Roch by Mass. ASTM International, West Conshohocken. Pennsylvania.

ASTM D3987-85(2004), 2004, Standard Test Method for Shake Extractron of Sold Waste with Water, ASTM Intemational, West Conshohocken, Penusylvania. 
RPP-PLAN-43820, Rev. 0

ASTM E19 15-07, 2007. Standard Test Methods for Anoly'sis of Metd Bearing Ores and Related Materals by Combustion Infrared-Absorption Spectronetry, ASTM International. West Conshohosken, Pennsylvania.

DOE O 414. IC, 2005. Quahty Assurance, U.S. Departntent of Encrgy, Washington, D.C.

DOE O 435.1, 1999, Radroactive Waste Managemen, U.S. Department of Energy, Washinglon. D.C.

EPA 1996, "Method 3052. Microwave Assisted Acid Digestion of Siliceous and Organically Based Matrices, Rev. 0. Test Methods for Evalnatng Solud Wastes: Phystcal/Chemeal Methods. EPA SW-846. Third Ed., 3000 series, pp. 3052-1-3052-20.

U.S. Environmental Protection Agency, Office of Solid Waste and Emergency Response, Washington, D.C.

EPA 2007a, "Method 6020A. Inductively Coupled Plasma-Atomic Emission Spectrometry." Rev. 1. Test Methods for Evaluatmg Sold Wastes: Physicall Chemcal Methods, EPA SW-846. Third Ed, 6000 series, pp. 6020A-1 - 6020A-30. U.S. Environnental Protection Agency, Office of Solid Waste and Emergency Response, Washington, D.C.

EPA 2007b, "Method 9056A. Deternination of Inorganic Anjons by Ion Chromalography," Rev. 1, Test Methods for Evaluatmg Solid Wastes: Phystcal Chemcal Methads. EPA SW-846. Third Ed., 9000 series, pp. 9056A-1 - 9056A-19, U.S. Euvironmental Protection Agency, Office of Solid Waste and Emergency Response. Washington. D.C.

Lee, W. and B. Batchelor, 2003, "Reductive Capacity of Natural Reductants." Envrommental Sorence \& Technology. Vol. 37, pp. 535-541.

MoGrail, B.P.. W.L. Eber1, D.H. Bacon and D.M. Strachan, 2001, "A Strategy to Conduct an Analysis of the Long-Term Performance of Low-Activity Waste Glass in a Shallow Subsurface Disposal System at Hanford." Appendix E of DOE/ORP-2000-24, Hanford Inmobized Low-Actwity Waste Performance Assessment: 2001 Version. Rev, 0. Department of Energy, Office of River Protection, Richland, Washington.

NIST SRM 676A, 2005, Standard Reference Matenal 676. Altmma Intermal Standard for Quomtative Analysss by $X-r a y$ Powder Diffroction. National Institute of Standards and Technology, U.S. Department of Commerce, Gajthersburg. Maryland.

PNNL-AGG-ICP-AES, 2008. Inductrvely Coupled Plasma - Optical Emrsson Spectrometry (ICP-OES) Anolysts, Pacific Northwest National Laboratory, Richland, Washington.

PNNL-AGG-41 5, 2008, Inductwely Coupled Plasma Mass Spectrometric (ICP-MS) Analysis, Rev. 2, Pacific Northwest National Laboratory, Richland, Washington.

PNNL-13364, 2000. Inorganc and Radiochemcal Analysts of $24 I-C \cdot I 04$ Tank Waste, Pacific Northwest National Laboratory, Richland, Washington. 
PNNL-13452, 2001, Vitrification and Product Testing of C-104 and AZ-102 Pretreated Situdge Wred with Flow'sheet Qtantites of Secondary Wastes, Pacific Northwest National Laboratory, Richland, Washington.

Rounds, S. A. 2006, "Alkalinity and Acid Neutralizing Capacity (Version 3.0)," U.S. Geological Survey National Field Manual for the Collection of Water-Quality Data. Techniques of Water-Resources Investigations Book 9. Chapter A6 Field Measurentents, Section 6.6, accessed 11/04/2009 from http://pubs.water.usgs.gov/twri9A6/

RPL-PIP-4, 2005, Preparmg Sealed Radonctive Samples for XRD and Other Purposes, Pacific Northwest National Laboratory, Richland. Washington.

RPP-13310. 2006. Madelng Data Package for an Intral Assessment of Clostre of the C Tank Farm. Rev, 1, CHzM HILL Hanford Group. Richland, Washington.

WHC-EP-0806, 1994, Tank 241-T-1/1 Characterization Report, Westinghouse Hanford Company, Richland, Washington.

WHC-SD-WM-TI-648, 1994, Tank Characterization Reference Gutde, Rev, 0, Los Alamos Technical Associates, Ketmewick, Washington. 